\title{
RELATIONSHIP BETWEEN ENVIRONMENTAL FACTORS AND PERSONAL HYGIENE WITH DIARRHEA AMONG CHILDREN UNDER FIVE IN WEST KOTAWARINGIN, CENTRAL KALIMANTAN
}

\author{
Dortua Lince Sidabalok¹), Samsudin²), I Made Djaja²) \\ ${ }^{1)}$ Masters Program in Environmental Health, Faculty of Public Health, \\ Universitas Indonesia \\ ${ }^{2}$ School of Health Sciences, Borneo Cendekia Medica \\ 3)Department of Environmental Health, Faculty of Public Health, Universitas Indonesia
}

\begin{abstract}
Background: Globally, nearly 1 million children die each year because of diarrhea. Diarrhea is a major public health problem in developing countries, including Indonesia. The occurrence of diarrhea has been known to be linked with poor hygiene and sanitation. This study aimed to determine the relationship between environmental factors and personal hygiene with diarrhea among children under five in West Kotawaringin, Central Kalimantan.
\end{abstract}

Subjects and Method: This was a cross-sectional study conducted at West Kotawaringn, Central Kalimantan. A total of 1,007 households with children under five was selected for this study. The dependent variable was diarrhea. The independent variables were access to drinking water, latrine ownership, type of latrine, environmental hygiene, children defecation habit, and disposing of children feces habit. The data were collected by a set of questionnaire and analyzed by multiple logistic regression

Results: The risk of diarrhea increased with absence of latrine ownership ( $\mathrm{OR}=1.93$; $95 \% \mathrm{CI}=1.28$ to $2.91 ; \mathrm{p}=0.002)$, sub-standard type of latrine $(\mathrm{OR}=1.88 ; 95 \% \mathrm{CI}=1.27$ to $2.78 ; \mathrm{p}=0.002)$, poor child defecation habit $(\mathrm{OR}=1.85 ; 95 \% \mathrm{CI}=1.26$ to $2.71 ; \mathrm{p}=0.002)$, and free disposal of child feces $(\mathrm{OR}=1.72 ; 95 \% \mathrm{CI}=1.28$ to $2.91 ; \mathrm{p}=0.007)$.

Conclusion: The risk of diarrhea increases with absence of latrine ownership, substandard type of latrine, poor child defecation habit, and free disposal of child feces.

Keywords: diarrhea, hygiene, behavior, environment, children under five

Correspondence:

Dortua Lince Sidabalok. Masters Program in Environmental Health, Faculty of Public Health, Universitas Indonesia, Depok, West Java. Email: lincebalok4th@gmail.com Mobile: 081361218156. 